\title{
Outsider Participation and Influence in Judicial Confirmation Hearings, 1979-2004
}

\author{
Lisa M. Holmes
}

In this paper outsider participation in confirmation hearings for U.S. Court of Appeals nominees from 1979 to 2004 is examined. Findings indicate that outsider testimony has been absent since 1995, and that the factors that determined whether or not outsiders testified prior to 1995 do not account for the elimination of outsider testimony in recent years. Outsiders continue to be involved in the confirmation process through the low-cost activity of submitting materials to the Senate Judiciary Committee for the hearing record. When such materials are submitted-whether in support of or in opposition to confirmation - the nominee is less likely to be confirmed. Even with the recent elimination of hearing testimony as an avenue for outsider involvement in the confirmation process, interested outsiders continue to influence confirmation prospects through the use of a low-cost, formal lobbying activity.

Stephen T. Early $(1977,100)$ described the U.S. Courts of Appeals as "perhaps the least-noticed of the regular constitutional courts" due to the nature of their work, the lack of attention placed on them by the press, and the little interaction that circuit court judges have with the public. This situation, however, belies the importance of the courts of appeals to law and policy in America, particularly in recent decades. The courts of appeals are an integral part of the federal judiciary, overseeing the federal district courts, acting as the courts of last resort for most federal litigation, and shaping law and policy (Banks 1999). Due to the growing caseload and scope of litigation brought before the circuit courts, the influence of this level of the federal judiciary over public policy has expanded (Songer 1991; Songer, Sheehan, and Haire 2000). Growing attention has therefore been placed on the courts of appeals by those interested in their importance to American law and policy.

Along with the heightened importance of the courts of appeals to the creation of legal policy, the selection process for lower court judges, particularly to the U.S. Courts of Appeals, has undergone tremendous change in recent years. Scholars have addressed many aspects of modern judicial appointment politics, including delay in the nomination and confirmation process (Binder and Maltzman 2002; Martinek, Kemper, and Van Winkle 2002; Massie, Hansford, and Songer 2004), changes in how the president selects nominees (Goldman 1997; Goldman et al. 2005), contention between

LISA M. HOLMES is an assistant professor in the Department of Political Science at The University of Vermont.

The American Review of Politics, Vol. 28, Fall, 2007: 205-227

(C)2007 The American Review of Politics 
the Senate and the president (Holmes and Savchak 2003), and the involvement of organized interests in the selection of lower court judges (Bell 2002a, 2002b; Caldeira, Hojnacki, and Wright 2000; Cohen 1998, Flemming, MacLeod, and Talbert 1998; Scherer 2005). Central to analyses of modern judicial appointment politics has been a focus on the increased politicization and interest group involvement in the confirmation process (Bell 2002a, 2002b; Goldman 2003; Hartley and Holmes 2002; Scherer 2005). These studies have found increased contention coupled with increased interest group involvement in the appointment process over the past few decades.

In this study, changes in the hearing process for federal court of appeals nominees are examined, focusing specifically on the involvement and influence of outside interests to the confirmation hearing process. Although the U.S. Constitution does not provide a formal role for those beyond the president and the Senate, outsiders have developed an interest in, and means to influence, the appointment process. In addition, participation by outsiders in the confirmation hearings before the Senate Judiciary Committee provides the most public, formal role granted to outsiders in the appointment process. The involvement of outsiders in the hearing process for nominees to the U.S. Courts of Appeals from 1979 to 2004 is examined, focusing on how outsiders attempt to influence the outcome through public hearing testimony and through submissions of materials to members of the Judiciary Committee. This study provides further explanation of change in the judicial appointment process in recent years, and also adds to our understanding of lobbying activity and the effectiveness of outsider involvement in the confirmation process.

\section{Outsider Involvement in the Judicial Confirmation Process}

Several previous studies have examined the role of interest groups in the judicial confirmation process. Many have focused on the involvement of organized interests in the confirmation of Supreme Court justices, finding that interest group lobbying has an influence on confirmation votes in the Senate (see Caldeira and Wright 1998; Segal, Cameron, and Cover 1992; Segal and Spaeth 1993). Others have focused attention on the activities of organized interests in the selection and confirmation of lower federal court judges (Bell 2002a, 2002b; Cohen 1998; Scherer 2005; Scherer, Bartels, and Steigerwalt 2007). These scholars have found that interest groups can influence both the length of delay in the confirmation process as well as the likelihood of confirmation success when they target nominees. 


\section{Formal Participation in Confirmation Hearings}

Previous research has found that when attempting to influence the legislative process, most lobbying conducted by organized interests occurs at the committee level (Wright 1996). Most of the work done on legislation is done in committee, with committee bills often going unchallenged on the floor, making this stage in the legislative process the most likely arena for organizations to dedicate their limited resources (Hojnacki and Kimball 1998; Wright 1996). Participation at congressional hearings is a particularly useful tool for those interested in influencing the legislative process in that hearings "provide a formal opportunity for representatives of organized interests to express their preferences for or against proposed or existing policies" (Wright 1996, 40). Wright (1996) goes on to explain that interest groups participate in congressional hearings by testifying in person or by submitting written comments to the committee, or both. Testifying in person is the preferred way for organizations to participate in hearings due to the high visibility and prestige associated with being invited to testify by committee members or their staffs.

Previous studies on interest group testimony at confirmation hearings have found that groups testify at hearings fairly infrequently, especially for nominations to lower court positions, largely due to the ability of Committee members to prevent groups from formally participating (Caldeira, Hojnacki, and Wright 2000). When interest groups do participate in the confirmation hearings of Supreme Court or lower court nominees, however, their involvement has been found to have an influence on both delay in the confirmation process and the likelihood of confirmation success (Bell 2002a, 2002b; Cohen 1998; Segal, Cameron, and Cover 1992; Segal and Spaeth 1993). Thus, interest groups may be allowed to participate in a formal capacity in the confirmation hearing process in order to provide senators with information useful to the confirmation decision. However, the desire of senators to allow groups to testify is tempered by time factors that may constrain how much outside involvement is going to be tolerated by the Judiciary Committee.

In light of the role that interest group mobilization played in Robert Bork's nomination to the U.S. Supreme Court in 1987, a great deal of speculation ensued that groups would begin to mobilize more frequently in an effort to influence the confirmation process through testimony, advertisements, and lobbying. However, recent studies have concluded that an increase in interest group testimony has not materialized (Caldeira, Hojnacki, and Wright 2000; Cohen 1998; Flemming, MacLeod, and Talbert 1998). Group participation in hearings through testimony has actually decreased since the early 1980s (Cohen 1998; Flemming, MacLeod, and Talbert 1998). 
Flemming, MacLeod, and Talbert (1998) conclude that this decrease in group testimony may be due to the difficulty of preventing confirmation once a nominee has been referred. Accordingly, groups attempt to influence the appointment process at earlier stages and utilize hearing testimony as a last ditch effort rather than as a routine activity. With interest groups increasingly cut off from the opportunity to influence the confirmation process through the formal channel of testifying at confirmation hearings, those interested in influencing the judicial selection process have opted for more informal lobbying efforts, including direct lobbying of individual senators and disseminating information about nominees (Bell 2002b; Maltese 1995). Recent studies have focused on the influence of less formal lobbying efforts by organized interests on the selection and confirmation of Supreme Court and lower court judges, finding that informal lobbying can affect confirmation prospects (Caldeira and Wright 1998; Scherer 2005).

Wright's (1996) examination of interest group activity in legislative hearings identifies a second avenue of influence that has generally been ignored in the literature on interest group involvement in confirmation hearings. Namely, outsiders can submit written materials on the hearing record, either in conjunction with or in lieu of witness testimony. This activity allows those outside the legislative process the ability to get information to Judiciary Committee members, but requires less in the way of time and resources on the part of both the outside interest and the Committee members. Although the use of record submissions has been recognized as a formal means of interest group participation in the confirmation process (see Bell 2002b), it is largely ignored in the scholarly literature in favor of a focus on either formal hearing testimony or other informal lobbying activity.

\section{Outsiders in the Confirmation Process}

In addition to downplaying the possibility of formal participation in the confirmation process through record submissions, previous research has tended to focus solely on the activities of organized groups interested in the judicial appointment process. In their examination of lower court confirmation hearings, however, Flemming, MacLeod, and Talbert (1998) determined that other actors-including administrative representatives, members of Congress, and the nominee's co-workers and friends-have participated in confirmation hearings as well. In addition, Scherer (2005) argued that much of the contention in the lower court appointment process in recent decades is due to the ability of the president and those in the Senate to use lower court appointment politics as a way to court favor with interested elites. Although organized groups have become particularly interested in appointments to the lower courts, other professional and political elites and observers choose to 
participate in the confirmation process as well. Since those unaffiliated with organized interests attempt to influence the confirmation process, their participation is also worthy of examination.

This analysis, focusing on the ability of interested outsiders to participate in the confirmation hearing process, addresses two limitations found in most previous studies on the subject. First, the definition of "outside involvement" is broadened to include not only representatives of organized interest groups, but to include the involvement of all interested participants in the hearings who do not enjoy a formal role in the confirmation process. Second, both confirmation hearing testimony and record submissions are focused upon in order to examine more fully the ability of interested observers to influence the confirmation process through formal means. This study thus provides a more detailed analysis of when and how interested observers participate in the process and whether such participation influences confirmation outcomes.

\section{Defining “Outsiders" to the Confirmation Process}

This study examines the role of all outside actors in the confirmation hearing process, rather than limit the analysis to the participation of organized interests only. "Outside actors" are defined as any individual or group participant who was not a current member of the presidential administration or the U.S. Congress at the time of the participation. ${ }^{1}$ Therefore, "outsiders" include interest groups, bar associations, judges, state government officials, and private citizens, with the exception of the American Bar Association. The ABA has played a quasi-formal role in the appointment process since the Eisenhower administration when the ABA began the practice of assessing and rating all judicial nominees and making those ratings available to the president and the Senate (Goldman 1997; Slotnick 1983). Although the ABA's formal role in the nomination process was removed by President George W. Bush in 2001 (Holmes and Savchak 2003), the ABA's unique role in the selection process for much of the time period of this study is thus better characterized as that of an inside actor.

Data for this analysis include all nominations to the U.S. Courts of Appeals (with the exception of those to the Federal Circuit) for whom hearings were held between 1979 and 2004, regardless of whether or not the nominee was successfully confirmed. The late 1970s represents an important turning point in the evolution of politicization in the lower court appointment process, and as such it is appropriate to begin an analysis of outsider involvement in the confirmation hearing process in 1979 (see Allison 1996; Hartley and Holmes 2002). In addition, the Senate Judiciary Committee first began keeping detailed records of judicial confirmation hearings in 1979, 
further justifying that year as an appropriate year to begin this analysis (Bell 2002a). Individuals who were nominated in successive congressional terms were only included more than once if a hearing was held in each term, whereas nominees with multiple hearing dates within the same term were included once, although data on outsider involvement in each hearing for that nominee were collected. The data set thus included a total of 279 nominees from 1979 to 2004.

Data on hearing testimony and record submissions were collected from the printed Confirmation Hearings on Federal Appointments published by the U.S. Government Printing Office. Additional data on nominees were collected from the Federal Judicial Center (at www.fjc.gov), the American Bar Association (at www.abanet.org), The Committee on the Judiciary's Legislative and Executive Calendar, and from the Lower Federal Court Confirmation database (at http://cdp.binghamton.edu).

\section{Hearing Testimony and Record Submissions over Time}

Table 1 provides information on outsider participation in confirmation hearings starting with the 96th Congress in 1979 and ending with the 108th Congress in 2004. Table 1 includes information on the proportion of nominees for whom any outside actor participated via hearing testimony or the submission of materials on the formal hearing record. "Hearing testimony" was defined according to whether one or more outside actors participated in person by testifying at the confirmation hearings, regardless of whether or not the outsider submitted materials on the hearing record. "Record submissions" were defined according to whether one or more outsiders submitted materials of any sort on the hearing record in lieu of hearing testimony, incorporating only the situation that occurred when outsiders utilized this as a strategy in itself rather than as a strategy used in conjunction with hearing testimony.

Previous studies have found that organized groups have testified at confirmation hearings less frequently in recent years (Caldeira, Hojnacki, and Wright 2000; Cohen 1998; Flemming, MacLeod, and Talbert 1998). With respect to outsider testimony in confirmation hearings for nominees to the courts of appeals, the findings reported in Table 1 are in agreement. Outsiders testified at the hearings at a fairly consistent rate through the 102nd Congress, testimony participation dropped sharply during the 103rd Congress, and has been non-existent ever since. With respect to the directionality of the outsider testimony that occurred at hearings from 1979 to 2004 , one or more outsiders testified in support of 6.8 percent of nominees, whereas outsiders testified in opposition to nominees slightly more often, with one or more outsiders testifying in opposition to 9.3 percent of nominees. 


\section{Table 1. Proportion of Nominations with Outsider Participation in Hearings, 1979-2004}

Means (Std Dev)

\begin{tabular}{rccc}
\hline Congress & Hearing Testimony & Record Submissions & $\mathrm{N}$ \\
\hline 96 & $0.205(.408)$ & $0.227(.424)$ & 44 \\
97 & $0.211(.419)$ & $0.105(.315)$ & 19 \\
98 & $0.214(.426)$ & $0.214(.426)$ & 14 \\
99 & $0.200(.407)$ & $0.267(.450)$ & 30 \\
100 & $0.294(.470)$ & $0.412(.507)$ & 17 \\
101 & $0.111(.323)$ & $0.278(.461)$ & 18 \\
102 & $0.143(.359)$ & $0.238(.436)$ & 21 \\
103 & $0.053(.229)$ & $0.421(.507)$ & 19 \\
104 & $0.00(.00)$ & $0.333(.488)$ & 15 \\
105 & $0.00(.00)$ & $0.333(.483)$ & 21 \\
106 & $0.00(.00)$ & $0.071(.267)$ & 14 \\
107 & $0.00(.00)$ & $0.316(.478)$ & 19 \\
108 & $0.00(.00)$ & $0.607(.497)$ & 28 \\
Total & $0.118(.324)$ & $0.301(.460)$ & 279 \\
\hline
\end{tabular}

Apart from these basic findings, the results in this paper differ some from earlier studies of interest group participation in confirmation hearings. Cohen (1998) also found that interest group involvement in confirmation hearings to the district and circuit courts dropped dramatically during the years in which Strom Thurmond (R-SC) chaired the Judiciary Committee, beginning in the 97th Congress. Cohen (1998) also found that group involvement rose again during the 100th and 101st Congresses to levels nearly as high as was seen when Ted Kennedy (D-MA) chaired the Committee in the 96th Congress. With respect to outsider testimony at court of appeals hearings alone, however, the Thurmond years did not see a drop in participation. Hearing participation rates began to drop in the 101st Congress, and hearing testimony was eliminated by the start of the 104th Congress. The elimination of outsider testimony coincides with the Republican Party winning control of the Senate after the Republican revolution in 1994, and has continued during both Democratic and Republican control of the Judiciary Committee.

A second finding from Table 1 is seen through a comparison of outsider hearing testimony with submissions on the hearing record. Although outsiders' use of submissions on the record vary widely from one Congress to the next, record submissions follow a very different pattern over time than is seen for hearing testimony. Through the 99th Congress, testifying at the 
hearings was a strategy employed by interested outsiders with approximately the same regularity as was submitting materials on the hearing record. As testimony before the Committee became a non-existent option for interested outsiders, however, record submissions have become more common, with nearly 61 percent of all nominations in the 108th Congress being the subject of submissions from interested outsiders. Furthermore, throughout the period of this analysis, nominees were more likely to have outsiders submit materials on the record in order to offer their support than in an attempt to obstruct the nomination. From 1979 to 2004, 27 percent of nominees have had materials submitted by outsiders who were supportive of confirmation, whereas only 9.7 percent of nominees have had materials submitted by outsiders opposed to their confirmation. Across the time period of this analysis, therefore, outsiders opposed to a nominee have utilized both hearing testimony and record submissions to similar extent. Those supportive of a particular nominee, however, have been more likely to use the less costly route of submitting materials on the record in an effort to help the nominee.

\section{Determining the Factors Related to the Likelihood of Outsider Testimony}

Noting a trend toward the elimination of outsider testimony in confirmation hearings does not answer the question of why this has occurred. Perhaps there have been systematic changes that can account for why outsider testimony was deemed useful for some hearings prior to 1995, but not after that year. This part of the analysis determines what factors influenced the presence or absence of outsider testimony prior to 1995 . It is followed by an examination of how these factors changed after 1995 to determine if the recent lack of outsider testimony may be attributed to changing nominee characteristics, political climate, or slowdown in the confirmation process in recent years.

\section{Dependent Variable}

This analysis was conducted by examining whether or not outsider testimony was allowed in confirmation hearings for nominees to the U.S. Courts of Appeals held between 1979 and 1994. The dependent variable for this analysis, therefore, is dichotomous, coded as "1" if one or more outsiders were allowed to testify (whether on behalf of or in opposition to the nominee) and " 0 " otherwise. Previous examinations of interest group influence in the confirmation process have utilized a dichotomous measure of interest group involvement rather than rely on an ordinal or count measure (Bell 2002a, 2002b; Scherer, Bartels, and Steigerwalt 2007). Scherer, Bartels, and Steigerwalt (2007) argued that with the nature of interest group 
coalitions involved in the confirmation process, most nominees either garnered substantial opposition or no opposition at all, lessening the need for a more subtle measure of interest group activity. The dichotomous nature of the dependent variable indicates that logistic regression analysis would be an appropriate method of analysis to utilize.

\section{Independent Variables}

Based on previous scholarship on confirmation politics and interest group activity in confirmation hearings, a number of independent variables were incorporated in the model. These independent variables were developed around three central themes: nominee considerations, political climate, and Judiciary Committee workload and scheduling considerations.

Nominee Considerations. Hearing testimony on the part of outside actors requires that the outsiders believe that their participation is worth the effort in that their information will be useful and influential (Mackenzie 1981). Furthermore, since outsiders can only participate in confirmation hearings when they are allowed to do so by members of the Judiciary Committee, the presence of outsider participation will be affected by whether or not members of the Committee need and desire such information. Nominee qualifications and characteristics are thus expected to influence the likelihood of outsider participation in the hearings. Nominees considered to be more highly qualified or who are more experienced should be less likely to require input from interested outsiders.

To determine the influence of nominee qualifications and experience, three variables measuring the nominee's previous judicial experience, previous prosecutorial experience, and the nominee's ABA rating were included. Previous judicial experience was coded as " 1 " if the nominee had any previous judicial experience at either the state or federal level, and " 0 " otherwise. Likewise, previous prosecutorial experience was coded as a "1" if the nominee had any previous prosecutorial experience at either the state or federal level, and " 0 " otherwise. The expectation was that nominees with previous experience, either judicial or prosecutorial, would be less likely to experience outsider testimony at the confirmation hearings. The ABA rating variable was coded on a 6-point scale, with "6" given to nominees who received the ABA's highest ratings and " 1 " given to nominees who received the lowest ratings. ${ }^{3}$ Based on previous studies concluding that higher ABA ratings have a beneficial influence on a nominee's prospects in the confirmation process, nominees with higher ABA ratings were expected to be less likely to have outsiders testify at their hearings than nominees with lower ABA ratings (Martinek, Kemper, and Van Winkle 2002; Scherer, Bartels, and Steigerwalt 2007; Solowiej, Martinek, and Brunnell 2005). 
Aside from experience and qualification considerations, some previous studies have found that females and minorities have faced increased difficulty in the confirmation process compared to their white, male counterparts (Hartley 2001; Martinek, Kemper, and Van Winkle 2002; Scherer, Bartels, and Steigerwalt 2007; Solowiej, Martinek, and Brunell 2005). Therefore, this study incorporated variables concerning the nominee's gender and ethnicity with the expectation that female and minority nominees would be more likely to garner outsider involvement in the confirmation process. The gender variable was coded as a " 1 " for a female nominee and a "0" for a male nominee. The minority variable was coded as a " 1 " for any nominee identified as African-American, Asian-American, Hispanic, Native American, or Arab-American, and a "0" otherwise (see Martinek, Kemper, and Van Winkle 2002).

In addition to characteristics and qualifications specific to the individual nominee, Mackenzie (1981) argued that outside actors are more likely to get involved in the appointment process when the position being filled is of greater salience to them. Nominations to the D.C. Circuit Court of Appeals may be more important to outsider actors as well as to members of the Judiciary Committee, due to the policy-making influence of positions on this court (Banks 1999). As such, a variable was included distinguishing nominations to the D.C. Circuit Court of Appeals (coded "1") from nominations to any other circuit court (coded "0"). The D.C. Court of Appeals variable was expected to have a positive relationship to the likelihood of outsider testimony in the confirmation hearings.

Political Considerations. Previous research on confirmation politics has included variables measuring the impact of political and electoral considerations. Mackenzie $(1981,194)$ argued that the "shape of the political terrain" affects the opportunity of outside actors to influence the appointment process. In previous studies on confirmation politics and delay, scholars have assessed the difficulty facing nominees when the president's relationship to the Senate is weakened by ideological differences or election year politics (Binder and Maltzman 2002; Johnson and Roberts 2005; Martinek, Kemper, and Van Winkle 2002; Moraski and Shipan 1999; Nixon and Goss 2001). The president's ideological relationship to the key senator representing the filibuster pivot in the Senate has been found to influence the confirmation process (Johnson and Roberts 2005; Moraski and Shipan 1999; Nixon and Goss 2001). Therefore, 1st dimension DW-NOMINATE scores (Poole and Rosenthal 1997) were used to calculate the absolute distance in the ideological scores for the president and the furthest filibuster pivot (located at the 40th and 60th percentiles, see Binder 1999) in the Senate. This president-filibuster ideological distance variable was expected to have a positive relationship to the dependent variable of outsider participation 
because outsiders should be more likely to be allowed to testify when the president is ideologically distant from the key filibuster pivot in the Senate. The presidential election year variable (coded as " 1 " if the confirmation hearing was held during a presidential election year and " 0 " otherwise) was expected to make outsider participation in confirmation hearings more likely due to the weakened position of the president during an election year.

Whereas a president is expected to enjoy less power and influence over the Senate during an election year, presidents typically enjoy more influence during their honeymoon year than later in their term (McCarty and Razaghian 1999). Therefore, there may be an expected decrease in the likelihood of outsider testimony in hearings during the honeymoon year than during other points in the president's term due to an increase in presidential power. However, new presidents typically usher in new judicial selection agendas and procedures (Goldman 1997), resulting in a possible increase in the likelihood of outsider testimony during the honeymoon year as members of the Judiciary Committee require more information to be provided on the new president's nominees. As such, a presidential honeymoon year variable was included and expected to have a positive impact on the dependent variable. The honeymoon variable was coded as " 1 " if the hearing was held during the first year of a president's first term in office, and " 0 " otherwise.

Having an ally in the form of a home-state senator on the Judiciary Committee can also influence the hearing process in two ways. First, the presence of an ally on the Judiciary Committee has been found to expedite the confirmation process and make a nomination more likely to be successful (Bell 2002a). In addition, with a home-state insider on the Judiciary Committee, other Committee members may be less likely to require additional information on the nominee. In consideration of this possible dynamic, a committee insider variable was included and expected to have a negative influence on the dependent variable. The committee insider variable was coded as " 1 " if the nominee had a home-state senator of either party seated on the Judiciary Committee at the time of the hearing, and " 0 " otherwise.

Workload and Hearing Scheduling Considerations. The opportunity afforded to outsiders regarding confirmation testimony may be influenced by the workload considerations of those on the Judiciary Committee. The allotting of hearing time to outsider testimony may be limited when the workload of the Committee members is high. The number of pending nominations to the circuit courts may limit the Committee's ability to dedicate hearing time to outsider testimony. The pending nominations variable counted the number of other nominees to the U.S. Courts of Appeals (excluding those to the Federal Circuit) awaiting the initiation of hearings at the time of the hearing and was expected to have a negative impact on the dependent variable. 
Table 2. Descriptive Statistics

\begin{tabular}{|c|c|c|c|c|}
\hline Variable & & $\mathrm{N}$ & Mean & Std Error \\
\hline Hearing Testimony & $\begin{array}{l}\text { Overall } \\
1979-1994 \\
1995-2004\end{array}$ & $\begin{array}{r}279 \\
182 \\
97\end{array}$ & $\begin{array}{l}0.118 \\
0.181 \\
0.000\end{array}$ & $\begin{array}{l}0.020 \\
0.029 \\
0.000 * * *\end{array}$ \\
\hline Judicial Experience $(-)$ & $\begin{array}{l}\text { Overall } \\
1979-1994 \\
1995-2004\end{array}$ & $\begin{array}{r}279 \\
182 \\
97\end{array}$ & $\begin{array}{l}0.573 \\
0.599 \\
0.526\end{array}$ & $\begin{array}{l}0.030 \\
0.036 \\
0.051\end{array}$ \\
\hline Prosecutorial Experience (-) & $\begin{array}{l}\text { Overall } \\
1979-1994 \\
1995-2004\end{array}$ & $\begin{array}{r}279 \\
182 \\
97\end{array}$ & $\begin{array}{l}0.305 \\
0.302 \\
0.309\end{array}$ & $\begin{array}{l}0.028 \\
0.034 \\
0.047\end{array}$ \\
\hline ABA Rating $(-)$ & $\begin{array}{l}\text { Overall } \\
1979-1994 \\
1995-2004\end{array}$ & $\begin{array}{r}279 \\
182 \\
97\end{array}$ & $\begin{array}{l}4.792 \\
4.764 \\
4.845\end{array}$ & $\begin{array}{l}0.089 \\
0.114 \\
0.141\end{array}$ \\
\hline Gender $(+)$ & $\begin{array}{l}\text { Overall } \\
1979-1994 \\
1995-2004\end{array}$ & $\begin{array}{r}279 \\
182 \\
97\end{array}$ & $\begin{array}{l}0.197 \\
0.148 \\
0.289\end{array}$ & $\begin{array}{l}0.024 \\
0.026 \\
0.046 * *\end{array}$ \\
\hline Minority $(+)$ & $\begin{array}{l}\text { Overall } \\
1979-1994 \\
1995-2004\end{array}$ & $\begin{array}{r}279 \\
182 \\
97\end{array}$ & $\begin{array}{l}0.158 \\
0.104 \\
0.258\end{array}$ & $\begin{array}{l}0.022 \\
0.023 \\
0.045^{* * *}\end{array}$ \\
\hline D.C. Court of Appeals $(+)$ & $\begin{array}{l}\text { Overall } \\
1979-1994 \\
1995-2004\end{array}$ & $\begin{array}{r}279 \\
182 \\
97\end{array}$ & $\begin{array}{l}0.079 \\
0.093 \\
0.051\end{array}$ & $\begin{array}{l}0.016 \\
0.022 \\
0.023\end{array}$ \\
\hline President-Filibuster Distance $(+)$ & $\begin{array}{l}\text { Overall } \\
1979-1994 \\
1995-2004\end{array}$ & $\begin{array}{r}279 \\
182 \\
97\end{array}$ & $\begin{array}{l}0.688 \\
0.632 \\
0.795\end{array}$ & $\begin{array}{l}0.009 \\
0.011 \\
0.005 * * *\end{array}$ \\
\hline Presidential Election Year $(+)$ & $\begin{array}{l}\text { Overall } \\
1979-1994 \\
1995-2004\end{array}$ & $\begin{array}{r}279 \\
182 \\
97\end{array}$ & $\begin{array}{l}0.190 \\
0.203 \\
0.165\end{array}$ & $\begin{array}{l}0.024 \\
0.030 \\
0.038\end{array}$ \\
\hline Presidential Honeymoon Year $(+)$ & $\begin{array}{l}\text { Overall } \\
1979-1994 \\
1995-2004\end{array}$ & $\begin{array}{r}279 \\
182 \\
97\end{array}$ & $\begin{array}{l}0.176 \\
0.187 \\
0.155\end{array}$ & $\begin{array}{l}0.023 \\
0.029 \\
0.037\end{array}$ \\
\hline Committee Insider (-) & $\begin{array}{l}\text { Overall } \\
1979-1994 \\
1995-2004\end{array}$ & $\begin{array}{r}279 \\
182 \\
97\end{array}$ & $\begin{array}{l}0.319 \\
0.203 \\
0.536\end{array}$ & $\begin{array}{l}0.028 \\
0.030 \\
0.051 * * *\end{array}$ \\
\hline Pending Nominations (-) & $\begin{array}{l}\text { Overall } \\
1979-1994 \\
1995-2004\end{array}$ & $\begin{array}{r}279 \\
182 \\
97\end{array}$ & $\begin{array}{l}3.319 \\
2.407 \\
5.031\end{array}$ & $\begin{array}{l}0.195 \\
0.211 \\
0.335^{* * *}\end{array}$ \\
\hline Time to Hearings $(+)$ & $\begin{array}{l}\text { Overall } \\
1979-1994 \\
1995-2004\end{array}$ & $\begin{array}{r}279 \\
182 \\
97\end{array}$ & $\begin{array}{r}108.699 \\
56.495 \\
206.650\end{array}$ & $\begin{array}{c}8.528 \\
4.045 \\
19.866^{* * *}\end{array}$ \\
\hline \multicolumn{5}{|c|}{ Significance level: ${ }^{*} \mathrm{p}<.05 ; * *_{\mathrm{p}}<.01 ; * * * \mathrm{p}<.001$} \\
\hline
\end{tabular}


Lastly, the time period between nominee referral and the initiation of hearings is used to gather needed information on a nominee as well as to delay hearings for political gain. Outsiders may take advantage of the time afforded to them to gather and organize such information (Hojnacki and Kimball 1998). The time to hearing variable, expected to have a positive impact on the dependent variable, counted the number of days between the initial referral date and hearing date for the nominee under consideration. For nominees with more than one hearing held during a single congressional term, the time to hearing variable was determined according to the date of the first hearing held.

Descriptive statistics on the dependant variable and the independent variables (including the expected direction of impact on the dependent variable) are included in Table 2. Table 2 also provides information on which variables have experienced a statistically significant change in means between the earlier era (prior to 1995 when outsiders participated to some degree in confirmation hearings) and the latter era (1995 and on when outsider participation was absent). As can be seen in Table 2, post-1995 nominations were more likely to be female and ethnic minorities, compared to the earlier cohort. Nominees were also more likely to have a home-state ally on the Senate Judiciary Committee. With respect to the political climate surrounding judicial appointments, hearings were more likely to occur when the president was more ideologically distant to the Senate's filibuster pivot after 1994. Lastly, the workload of the Judiciary Committee has changed, with more nominations pending at the time of hearing after 1994, and longer delays prior to the initiation of hearings than in the earlier era. None of the other independent variables experienced a statistically significant change between the two time periods. Given that many variables related to nominee characteristics and the hearing environment have changed since 1994, these variables may account for why outsider testimony has not been present in recent years.

\section{Results}

The results of the logistic regression model analyzing outsider participation in the confirmation hearings from 1979 through 1994 are provided in Table 3. Given that outsider participation was absent from 1995 onward, this analysis serves to explain the factors relevant to the presence or absence of outsider testimony prior to that year. Of the nominee characteristic variables, both ABA rating and previous judicial experience had a statistically significant influence on the dependent variable, although the judicial experience variable was significant in the opposite direction than expected. Nominees with higher ABA ratings were less likely to experience outsider testimony 
Table 3. Logistic Regression of the Presence of Outsider Hearing Testimony, 1979 to 1994

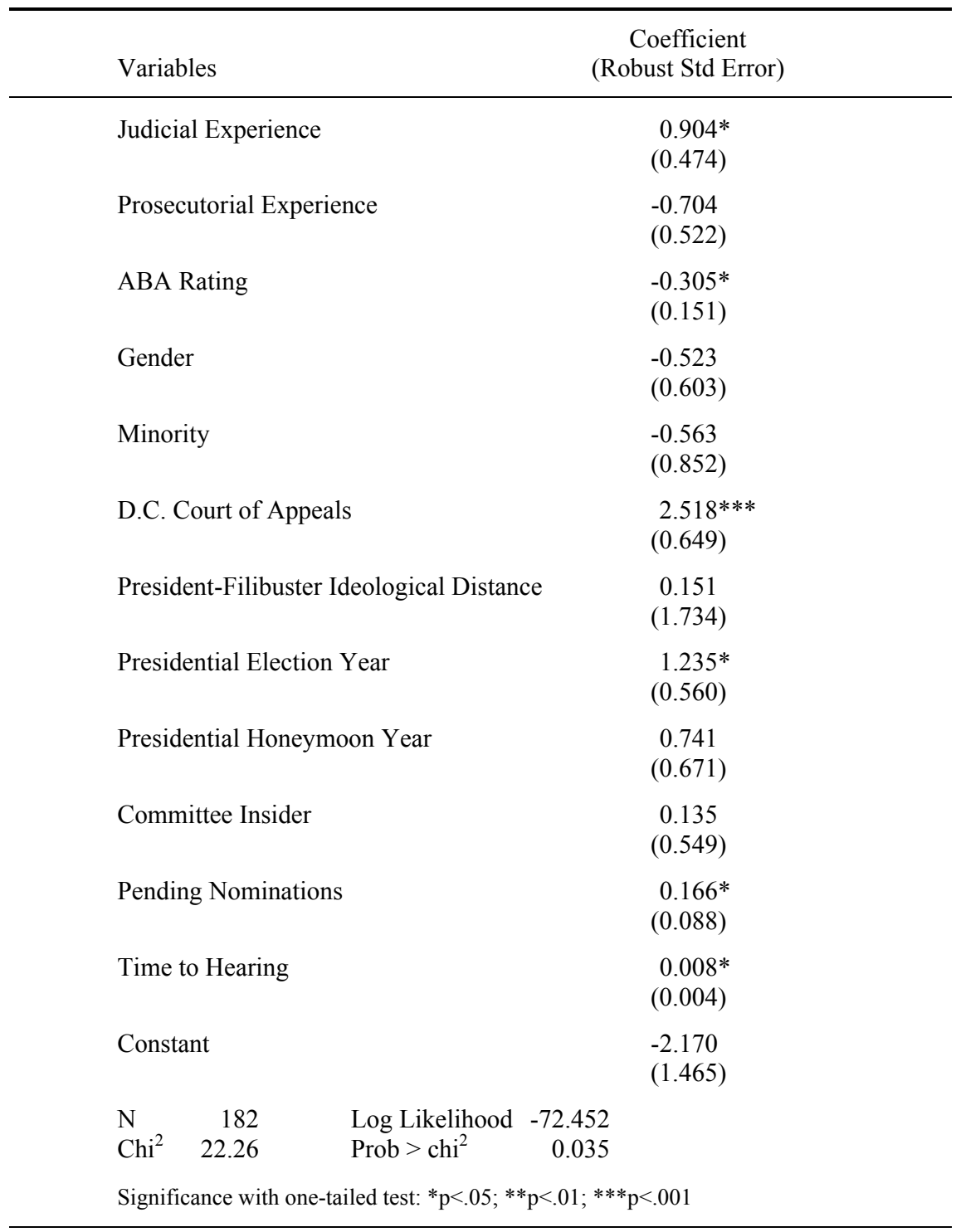


during their hearings, whereas those with previous judicial experience were more likely to have outsiders present to testify. The judicial experience impact, however, is not completely counterintuitive, given that nominees with previous judicial experience may have been more likely to have a public paper trail that invited outsider interest. As expected, hearings for nominees to the D.C. Circuit Court of Appeals as well were more likely to have outsider testimony than were hearings for nominees to other courts.

As for the political consideration variables, hearings held during election years were more likely to see outsider testimony than were hearings held at other stages in the presidential election cycle, as expected. A president faced with an ideologically distant Senate, however, did not serve to make outsiders statistically more likely to testify, and having an insider on the Committee did not make outsiders less likely to testify. Workload considerations did have a statistically significant impact on outsider participation. As expected, lengthier delays between referral and hearing dates resulted in a greater likelihood of outsider participation. And, there is evidence that a higher workload, as defined by the number of pending circuit court nominees awaiting hearings, actually increased the likelihood of outsider participation against the expectation.

These results indicate that certain nominee characteristics, political factors, and workload consideration did affect the likelihood that outsiders would testify at confirmation hearings from 1979 to 1994 . These findings are important in explaining what drove outsider testimony during a period of time during which outsiders were invited to participate in the hearings. They are also useful in helping to explain what may have changed beginning in 1995 to render outsider testimony absent. As explained previously, some of the independent variables experienced a statistically significant change in means between the two eras of interest to this analysis. Specifically, nominee gender and ethnicity, the ideological distance between the president and the Senate filibuster pivot, the presence of an insider on the Judiciary Committee, and the two workload variables (pending nominations and time to hearing) all displayed statistically different means after 1994 than they did between 1979 and 1994. However, gender, race, the president-filibuster pivot ideological distance, and the presence of a Committee insider did not have a statistically significant impact on the likelihood of outsider testimony prior to 1995. Therefore, it would be unexpected that changes in these variables would account for the absence of outsiders in the hearings after 1995. In addition, having a greater number of pending nominations and a lengthier period of time between referral and hearing served to increase the likelihood of outsider testimony prior to 1995 . The changes in these variables, then, cannot help to explain why outsiders were absent in more recent hearings. 
What these results indicate is that none of the relevant factors that contributed to the likelihood of outsider participation prior to 1995 can explain why outsiders are absent from the process today. If the variables that were relevant prior to 1995 were still relevant, then outsiders would be testifying in the confirmation hearings. Given that hearing delay in particular experienced a significant increase since 1995, we may even have expected outsiders to be allowed to testify more often in hearings in recent years than in the earlier era. Clearly, the year 1995 (coinciding with the Republican takeover of Congress) represented an important turning point in how confirmation hearings were conducted. Outsiders simply no longer participated, and their absence does not appear to be related to changes in nominee characteristics, the political context during which the hearing is being held, or committee workload or scheduling considerations.

\section{Does Outsider Participation Influence Confirmation Success?}

Having determined that outsider testimony in confirmation hearings no longer occurs for reasons that are unrelated to the factors that influenced outsider presence prior to 1995 , but that outsiders continue to submit materials on the hearing record, it is important to determine whether or not outsider participation influences the likelihood of a nominee's success in the confirmation process. In this part of the analysis, the likelihood that a nominee will be successfully confirmed during the Congress in which the hearing took place is examined. ${ }^{4}$ Overall, 89 percent of all nominees for whom hearings were held between 1979 and 2004 were confirmed during that Congress. However, as can be seen from the results in Table 4, the likelihood of success changes with time and the presence of outsider activity in the hearings.

Throughout the period under review in this analysis (1979-2004), the likelihood of nominee success was not affected by whether or not outsiders were invited to testify in the confirmation hearings. This finding, however, is influenced by the absence of any outsider testimony after 1994. Nominees referred prior to 1995 for whom outsiders were invited to testify were less likely to be confirmed (at $87.9 \%$ ) than was the case if no outsider testimony was present (at 98.0\%).

With respect to the less-costly activity of submitting materials on the hearing record, nominee success was influenced by the presence or absence of such materials throughout the period of study. From 1979-2004, nominee success rates dropped from 95.4 percent when no outsiders submitted mateials to only 75.0 percent if such materials were present. Since 1994, these results have been even more apparent. Nominee success rates dropped from 90.2 percent with no submissions to only 52.8 percent when submissions 
Table 4. Nominee Success Rates

\begin{tabular}{crcl}
\hline & $\mathrm{N}$ & Mean & Std Error \\
\hline 1979-2004 & 279 & 0.892 & 0.019 \\
with hearing testimony & 33 & 0.879 & 0.058 \\
no hearing testimony & 246 & 0.894 & 0.020 \\
with record submissions & 84 & 0.750 & $0.048^{* * *}$ \\
no record submissions & 195 & 0.954 & 0.015 \\
1979-1994 & 182 & 0.962 & 0.014 \\
with hearing testimony & 33 & 0.879 & $0.058^{* *}$ \\
no hearing testimony & 149 & 0.980 & 0.012 \\
with record submissions & 48 & 0.917 & $0.040 \#$ \\
no record submissions & 134 & 0.978 & 0.013 \\
1995-2004 & 97 & 0.763 & 0.043 \\
with hearing testimony & 0 & $\mathrm{n} . \mathrm{a}$. & $\mathrm{n} . \mathrm{a}$. \\
no hearing testimony & 97 & & \\
with record submissions & 36 & 0.528 & $0.084^{* * *}$ \\
no record submissions & 61 & 0.902 & 0.038 \\
Significance level: \#p $<.10 ; * \mathrm{p}<.05 ; * \mathrm{p}<.01 ; * * * \mathrm{p}<.001$ & & \\
\hline
\end{tabular}

were present. These results indicate that nominees are less likely to be confirmed when outsiders formally lobby members of the Judiciary Committee through record submissions. And, the effect of this form of participation is particularly apparent in the post-1994 era, when outsider testimony has been absent.

In order to determine further whether there is a relationship between record submissions and nominee success, the results of two logistic regression analyses of nominee success from 1979 to 2004 are provided in Table 5 . The dependent variable of nominee success in this model is coded " 1 " if the nominee was successfully confirmed during the Congress in which the hearing was held, and " 0 " otherwise. In the first model, the main independent variable (submissions) measured whether or not outsiders submitted materials on the hearing record, coded as " 1 " if such materials were present and " 0 " otherwise. This operationalization took no consideration of the directionality of the outsider participation - only its presence or absence. In the second model, two main independent variables were created to determine whether materials submitted on behalf of or in opposition to the nominee influenced the nominee's success in the confirmation process. These two independent variables (submissions in support and submissions in 
Table 5. Logistic Regression of Nominee Success, 1979-2004

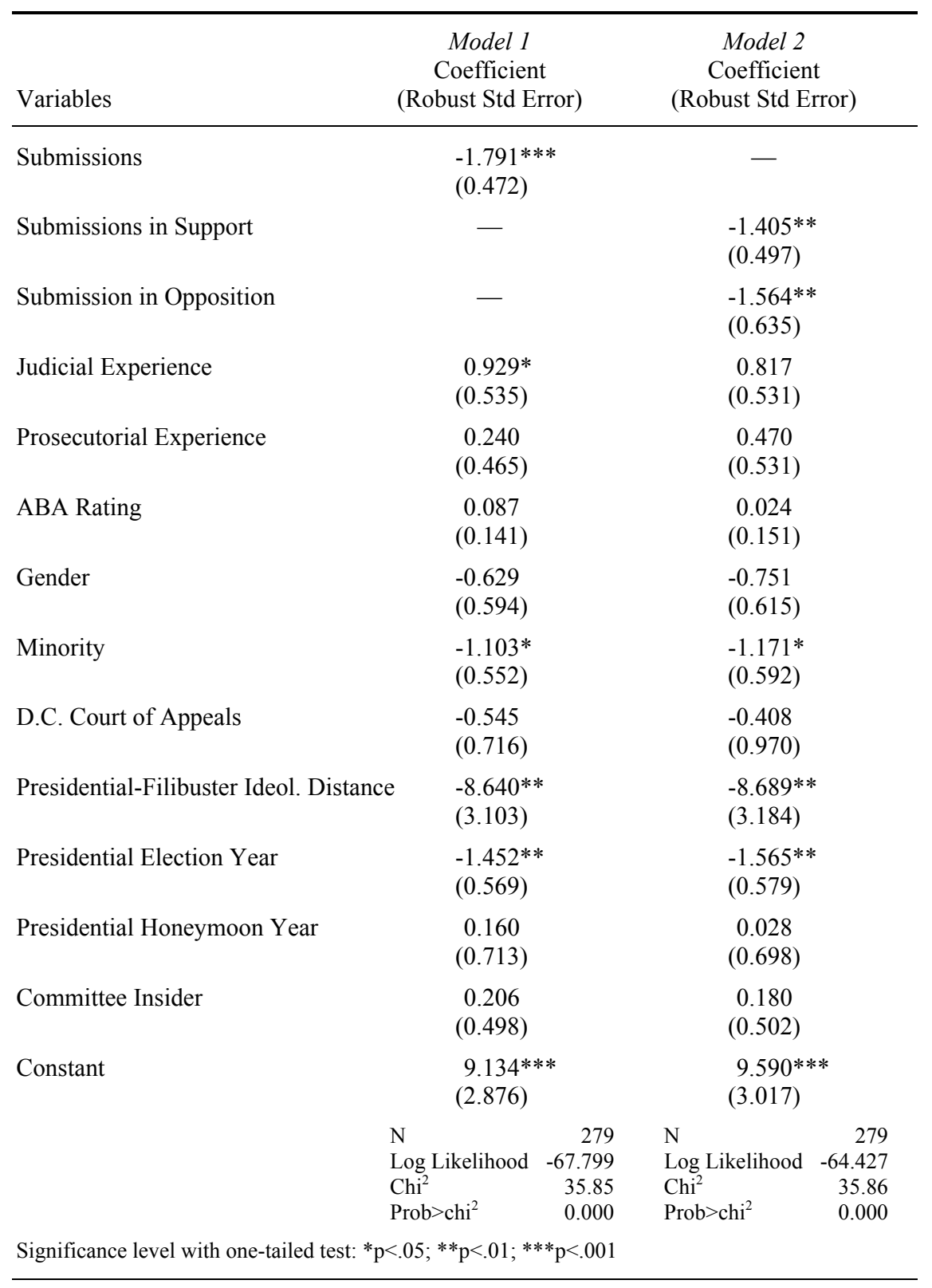


opposition) were each coded "1" if outsiders submitted such materials, and " 0 " otherwise. The two models also incorporated most of the variables from the logistic regression analysis of hearing participation in Table 3, with the exception of the two Judiciary Committee workload and scheduling variables. As can be seen from Model 1, when outsiders chose to get involved in the confirmation process, a nominee was less likely to be confirmed. As was found in previous studies, outsider involvement in the confirmation process served to hinder the confirmation prospects of lower court nominees (Bell 2002a, 2002b; Cohen 1998; Scherer, Bartels, and Steigerwalt 2007).

According to the results of the second model, nominees were less likely to be confirmed, controlling for other relevant variables, if outsider materials were placed on a nominee's hearing record in support of the nominee's confirmation, as well as if materials were submitted in opposition to confirmation. The presence of submissions in support of a nominee's confirmation had a slightly larger substantive influence on the likelihood of confirmation success than did submissions opposing the nominee, with a factor change in odds of 0.245 for a unit increase in the submissions in support variable, and a factor change in odds of 0.209 for a unit increase in the submissions in opposition variable. To determine whether supportive submissions influenced the confirmation prospects of a nominee who was not the subject of opposition submissions, the model was run excluding cases where submissions were made in opposition to the nominee. The submissions in support variable retained its statistically significant and negative impact on the dependent variable even when nominees who were targeted by opposition submissions were excluded.

The findings of these logistic regression analyses substantiate the descriptive results provided in Table 4, indicating that outsiders can influence the confirmation process when engaging in activities that are less costly and public than testifying at the confirmation hearings. In recent years, the absence of outsider testimony in confirmation hearings does not prevent outsiders from influencing the likelihood that a nominee will be confirmed. When outsiders get formally involved in the confirmation process, even by simply submitting materials on the hearing record, a nominee is less likely to be confirmed. Lastly, such involvement is problematic for nominees even when outside involvement is motivated by a desire to help the nominee. With respect to interest group testimony at the confirmation hearings, interest group participation was found to lessen the likelihood of confirmation, and a nominee's confirmation prospects were further harmed when more of the testimony was in opposition to the nominee (Bell 2002b; Cohen 1998). Here, confirmation prospects were found to be lessened regardless of the intentions of those submitting the materials. 


\section{Conclusions}

Without the opportunity to testify at confirmation hearings on court of appeals nominees, interest groups have been found to rely on a variety of informal lobbying tactics in an attempt to influence the selection and confirmation of lower court judges (Bell 2002b; Caldeira, Hojnacki, and Wright 2000; Scherer 2005). This study does not provide a systematic assessment of all of the ways in which organized groups informally lobby the president or those in the Senate. By examining submissions on the hearing record, however, it has been determined that interested parties continue to involve themselves in the confirmation process through the formal means of submitting letters and other materials on the hearing record. In addition, this study expands the focus of previous literature by including into the analysis the colleagues, clients, government actors, and other interested outsiders who involve themselves in the confirmation process.

The findings of this study provide many insights into changes in the modern judicial confirmation process. For nominations to the U.S. Courts of Appeals, outsiders no longer testify at the confirmation hearings, starting in 1995. Since that year, the absence of outsider testimony is unrelated to any of the factors that influenced whether or not outsiders were invited to participate prior to 1995 , indicating that confirmation hearing politics and procedures have changed substantially, starting when the Republicans took control of the Senate during the Clinton administration in 1995. Outsiders simply have not been invited to testify since then, regardless of the president's ideological relationship to those in the Senate or increased delay in the confirmation process. With the hearing testimony avenue closed to interested outsiders starting in 1995, these outsiders have focused more attention on influencing senators in other ways, through avenues which include the formal submission of materials on the hearing record. This activity, furthermore, is related to confirmation success even when such activity is motivated by a desire to help the nominee.

The low-cost nature of the record submissions activity, coupled with the substantial majority of hearings for which materials were submitted in the 108th Congress suggests that this is an activity in which interested outsiders will likely continue to engage. Scherer (2005) explains the conflict and politicization in the modern lower court confirmation process by arguing that interested elites signal their opposition to nominees in a variety of ways and that those in the Senate respond accordingly in order to satisfy their particular constituency. Interested outsiders can send such a signal by submitting materials to the Senate Judiciary Committee. However, signaling support of a nominee poses problems for that nominee's chances of confirmation, even in the absence of any accompanying opposition submissions. 
Outsider testimony at the confirmation hearings for U.S. Court of Appeals nominees appears to be a thing of the past, but outsiders still exert influence over confirmation politics through the formal but low-cost activity of submitting materials on the hearing record. Whether or not such activity continues to hamper a nominee's chances of confirmation even when the participant is signaling support of the nominee will be an important question to consider in the evolving politicization of the modern lower court appointment process.

\section{NOTES}

${ }^{1}$ Members of the House of Representatives routinely participate in a semi-official capacity in the confirmation process by introducing home-state nominees (either in addition to or in lieu of participation by the home-state senators) and are thus more appropriately categorized as insiders to the appointment process, even though they have no role in confirming judges.

${ }^{2}$ Outsiders who testify at confirmation hearings typically submit materials on the record as well, if only a written copy of their statements made before the committee.

${ }^{3}$ The specific coding scheme for the ABA rating variable was as follows:

$1=$ not qualified

2 = qualified (majority) / not qualified (minority)

$3=$ qualified

4 = qualified (majority) / well qualified (minority)

$5=$ well qualified (majority) / qualified (minority)

$6=$ well qualified or better

${ }^{4}$ An initially unsuccessful nominee may, of course, be referred again in the next Congress and may be successfully confirmed. For this analysis, however, I am only concerned with whether or not a nominee was successfully confirmed during the Congress in which the hearing occurred.

\section{REFERENCES}

Allison, Garland W. 1996. Delay in the Senate Confirmation of Federal Court Nominees. Judicature 80:8-15.

Banks, Christopher P. 1999. Judicial Politics in the D.C. Circuit Court. Baltimore, MD: The Johns Hopkins University Press.

Bell, Lauren Cohen. 2002a. Senatorial Discourtesy: The Senate's Use of Delay to Shape the Federal Judiciary. Political Research Quarterly 55:589-608

Bell, Lauren Cohen. 2002b. Warring Factions: Interest Groups, Money, and the New Politics of Senate Confirmation. Columbus, OH: The Ohio State University Press.

Binder, Sarah A. 1999. The Dynamics of Legislative Gridlock, 1947-1996. American Political Science Review 93:519-533.

Binder, Sarah A., and Forrest Maltzman. 2002. Senatorial Delay in Confirming Federal Judges, 1947-1998. American Journal of Political Science 46:190-199.

Caldeira, Gregory, Marie Hojnacki, and John R. Wright. 2000. The Lobbying Activities 
of Organized Interests in Federal Judicial Nominations. The Journal of Politics 62:51-69.

Caldeira, Gregory A., and John R. Wright. 1998. Lobbying for Justice: Organized Interests, Supreme Court Nominations, and the United States Senate. American Journal of Political Science 42:499-523.

Cohen, Lauren M. 1998. Missing in Action: Interest Groups and Federal Judicial Appointments. Judicature 82:119-123.

Early, Stephen T., Jr. 1977. Constitutional Courts of the United States: The Formal and Informal Relationships between the District Courts, the Courts of Appeals, and the Supreme Court of the U.S. Totowa, NJ: Littlefield, Adams \& Co.

Flemming, Roy B., Michael C. MacLeod, and Jeffrey Talbert. 1998. Witnesses at the Confirmations? The Appearance of Organized Interests at Senate Hearings of Federal Judicial Appointments, 1945-1992. Political Research Quarterly 51:617-631.

Goldman, Sheldon. 1997. Picking Federal Judges: Lower Court Selection from Roosevelt through Reagan. New Haven, CT: Yale University Press.

Goldman, Sheldon. 2003. Assessing the Senate Judicial Confirmation Process: The Index of Obstruction and Delay. Judicature 86:251-257.

Goldman, Sheldon, Elliot Slotnick, Gerard Gryski, and Sara Schiavoni. 2005. W. Bush's Judiciary: The First Term Record. Judicature 88:244-275.

Hartley, Roger E. 2001. Senate Delay of Minority Judicial Nominees: A Look at Race, Gender, and Experience. Judicature 84:190-197.

Hartley, Roger E., and Lisa M. Holmes. 2002. An Invigoration of 'Consent?' The Increasing Senate Scrutiny of Lower Federal Court Nominees. Political Science Quarterly 117:259-278.

Hojnacki, Marie, and David C. Kimball. 1998. Organized Interests and the Decision of Whom to Lobby in Congress. American Political Science Review 92:775-790.

Holmes, Lisa, and Elisha Savchak. 2003. Judicial Appointment Politics in the 107th Congress. Judicature 86:232-239.

Johnson, Timothy R., and Jason M. Roberts. 2004. Presidential Capital and the Supreme Court Confirmation Process. The Journal of Politics 66:663-683.

Mackenzie, G. Calvin. 1981. The Politics of Presidential Appointments. New York: The Free Press.

Maltese, John Anthony. 1995. The Selling of Supreme Court Nominees. Baltimore: The Johns Hopkins University Press.

Martinek, Wendy L., Mark Kemper, and Steven R. Van Winkle. 2002. To Advise and Consent: The Senate and Lower Federal Court Nominations, 1977-1998. The Journal of Politics 64:337-361.

Massie, Tajuana D., Thomas G. Hansford, and Donald R. Songer. 2004. The Timing of Presidential Nominations to the Lower Federal Courts. Political Research Quarterly 57:145-154.

McCarty, Nolan, and Rose Razaghian. 1999. Advice and Consent: Senate Responses to Executive Branch Nominations, 1885-1996. American Journal of Political Science 43:1122-1143.

Moraski, Bryon J., and Charles R. Shipan. 1999. The Politics of Supreme Court Nominations: A Theory of Institutional Constraint and Choices. American Journal of Political Science 43:1069-1095.

Nixon, David C., and David L. Goss. 2001. Confirmation Delay for Vacancies on the Circuit Court of Appeals. American Politics Research 29:246-274.

Poole, Keith, and Howard Rosenthal. 1997. Congress: A Political-Economic History of Roll Call Voting. New York: Oxford University Press. 
Scherer, Nancy. 2005. Scoring Points: Politicians, Activists, and the Lower Federal Court Appointment Process. Stanford, CA: Stanford University Press.

Scherer, Nancy, Brandon L. Bartels, and Amy Steigerwalt. 2007. Sounding the Fire Alarm: The Role of Interest Groups in the Lower Federal Court Confirmation Process. Paper presented at the annual meeting of the Southern Political Science Association, New Orleans.

Segal, Jeffrey, Charles M. Cameron, and Albert D. Cover. 1992. A Spacial Model of Roll Call Voting: Senators, Constituents, Presidents, and Interest Groups in Supreme Court Confirmations. American Journal of Politics 36:96-121.

Segal, Jeffrey A., and Harold J. Spaeth. 1993. The Supreme Court and the Attitudinal Model. New York: Cambridge University Press.

Slotnick, Elliot E. 1983. The ABA Standing Committee on Federal Judiciary: A Contemporary Analysis. Judicature 71:317-324.

Solowiej, Lisa A., Wendy L. Martinek, and Thomas L. Brunnell. 2005. Partisan Politics: The Impact of Party in the Confirmation of Minority and Female Federal Court Nominees. Party Politics 11:557-577.

Songer, Donald R. 1991. The Circuit Courts of Appeals. In The American Courts: A Critical Assessment, ed. John B. Gates and Charles A. Johnson. Washington, DC: CQ Press.

Songer, Donald R., Reginald S. Sheehan, and Susan B. Haire. 2000. Continuity and Change on the United States Courts of Appeals. Ann Arbor, MI: The University of Michigan Press.

Wright, John R. 1996. Interest Groups and Congress: Lobbying, Contributions, and Influence. Boston: Allyn and Bacon. 
